\title{
TESTING FOR STRATEGY-STRUCTURE FIT AND ITS IMPORTANCE FOR PERFORMANCE
}

\author{
Ana Aleksić* \\ Sanda Rašić Jelavic ***
}

Received: 19. 10. 2016

Preliminary communication

Accepted: 9. 6.2017

UDC 005.72(467.5)

Understanding different organizational elements, their mutual influence and creating congruence among them has been recognized as an important determinant of organizational performance. These complex interrelationships, and necessity of creating a fit between them, raises the question of how to align different organizational elements to contribute to overall organizational performance. In that sense, this paper addresses the issue of fit and, more specifically, analyses the presence and influence of strategy-structure fit on organizational performance. By using Miles and Snow typology, our goal was to capture and determine the pattern of relationships between strategy, structure, and strategy implementation processes and their influence on organizational performance. This paper presents results of a cross-sectional field research on a sample of 113 organizations in order to gain a better understanding of strategystructure fit and its relation to performance. Results reinforce the existing literature and confirm the importance of fit among strategy, structure and strategy implementation process for higher levels of organizational performance.

Key-words: Organization, Strategy, Structure, Fit, Performance, Croatia

\section{INTRODUCTION}

One of the key concepts in strategic management and organizational theory is the concept of fit, seen as the corner stone of the organization's strategic

\footnotetext{
* Ana Aleksić, PhD, Assistant professor, Department of Organization and Management, Faculty of Economics and Business Zagreb, University of Zagreb, Trg J. F. Kennedy 6, 10000 Zagreb, E-mail: aaleksic@efzg.hr

** Sanda Rašić Jelavić, PhD, Associate professor, Department of Organization and Management, Faculty of Economics and Business Zagreb, University of Zagreb, Trg J. F. Kennedy 6, 10000 Zagreb, E-mail: srasic@efzg.hr
} 
Management, Vol. 22, 2017, 1, pp. 85-102

A. Aleksić, S. Rašić Jelavić: Testing for strategy-structure fit and its importance for ...

development (Hill and Cuthbertson, 2011). Nadler and Tushman (1980) state that fit between the two elements is defined as the degree to which the needs, requirements, objectives, purpose and/or structure of one element is in accordance with the needs, requirements, objectives, purpose and/or structure of another element. The concept itself emphasizes the importance of harmonization between complex organizational elements in order for them to reinforce one another. In other words, as Carmeli and Tishler state (2004: 1261), the interaction amongst the elements becomes complementary in that the value of one element is increased by the presence of other elements.

In the context of organization, Siggelkow (2001) makes the distinction between internal fit seen as a coherent configuration of activities inside an organization and external fit defined as an appropriateness of the configuration given the environmental conditions faced by the firm. Miller (1996) states that the internal fit among elements of an organization can be evidenced by the degree to which strategy, structure and systems complement one another. They reinforce each other and this can result in a cycle of mutual cause and effect that tightens the relationship among them (Andrews et al., 2009). Many theorists emphasize that organizations need to have interdependent and mutually supportive strategy, structure and processes in order to be successful (e.g. Venkatraman and Camillus, 1984; Hamilton and Shergill, 1992; Xu et al., 2006; Garengo and Bernardi, 2007; Roberts, 2007; Cunliffe, 2008; Aagaard, 2016). This high mutual reinforcement leads to a high degree of fit that strengthens organizational effectiveness and creates superior performance (Burton and Obel, 2004; Hsieh and Chen, 2011). At the same time, many empirical studies suggest that there is a connection between the existence of the fit and increased effectiveness of the firm (e.g. Olson et al., 2005; Xu et al., 2006; Andrews et al., 2009; Camuffo and Wilhelm, 2016).

Miles and Snow typology of strategy (1984) allows us to understand organizational performance with respect to specific relationship between the four strategic types and environment. Each of the strategic types should be characterized by specific internal organizational settings that need to support chosen strategy and its implementation in order for organization to accomplish its strategic goals in a certain environment. The question that rises is how to align these elements in order to achieve strategy-structure fit, and transform these mutual relations into higher levels of organizational performance. In that sense, the aim of the current study is to capture and determine the pattern of relationships between strategy, structure, and strategy implementation processes and their influence on organizational performance. Therefore, we conducted a cross-sectional field research on a sample of 113 organizations to gain a better 
Management, Vol. 22, 2017, 1, pp. 85-102

A. Aleksić, S. Rašić Jelavić: Testing for strategy-structure fit and its importance for ...

understanding of the relationship between strategy-structure fit and performance.

The paper is structured as follows. After a short introduction, we give a theoretical overview of characteristics and different approaches in the studies of fit, as well as its importance for performance. Additionally, Miles and Snow typology is shortly presented and analyzed in the context of strategy-structure fit. Methodology and main results of our empirical research are presented in the next section. The paper concludes with a discussion on major findings of the study, research limitations and possibilities for further research.

\section{ORGANIZATIONAL FIT - CHARACTERISTICS AND APPROACHES}

Two concepts of fit, internal fit between organizational strategy and structure on one side, and external fit between strategy and environment of the organization, on the other, have been extensively analyzed in the existing literature. What is common to all of these is that to understand the performance of a fit, it is necessary to analyse the firm as a system of interconnected choices: choices with respect to activities, policies and organizational structures, capabilities, and resources (Siggelkow, 2001: 838).

According to Porter (1996), fit refers to the network of closely related elements and activities that emerged in a specific organizational context and thus present an important obstacle for imitation by competitors. In addition to helping the firm to manage their resources more effectively, fit enables synergy effects throughout the firm, improved procurement, allocation and use of resources and increased earning capability. It also helps an organization to reduce operational costs, to respond to environmental changes and to take advantage of new opportunities such as internationalization (Newport et al., 1991; Hsieh and Chen, 2011; Swoboda, 2016). A useful metaphor for thinking about the importance of the fit is observing different elements of the organization as puzzles that give a complete picture and fulfill its purpose only when they properly fit together (Aleksic, 2012).

As mentioned before, the most common division in the study of fit is that it can be studied as an internal fit, relating to compliance of certain organizational elements with the selected strategy, and as an external fit that relates to the harmonization of certain elements of the firm with the environment in which it operates. Various perspectives however, emphasize different elements of internal organizational fit. For instance, one of the first models on congruence, 
Management, Vol. 22, 2017, 1, pp. 85-102

A. Aleksić, S. Rašić Jelavić: Testing for strategy-structure fit and its importance for ...

Nadler and Tushman model (1980), emphasizes the importance of fit among tasks, individuals, formal and informal organization and their fit with organizational inputs and strategy. Burke and Litwin (1992) emphasize the importance of different transactional and transformational variables and their mutual correspondence. The concept of fit is central also to the Star model, where each of the elements of the model, i.e. structure, process, reward system and human resource management practices should reinforce the selected strategy (Kates and Galbraith, 2007). Traditionally, however, organizational structure together with strategy has been seen as a basic element of organization. This strong emphasis on the importance of structure is a consequence of its importance in the allocation of resources and different organizational activities, and in defining positions of power and authority. In the current literature, great attention is given to the fit between strategy and structure of the firm. Although this has been an area of interest for many years (see Park et al., 2011), it remains equally important for further analytical pursuit in the present. In this paper, we also focus on strategy-structure fit, realizing that this may be considered as a more traditional approach.

Once the strategy has been defined, it is important to harmonize different organizational activities and processes with the strategy itself. This is a crucial but often ignored element (Marr, 2008), but a necessary one for understanding that strategic and organizational choices need to be considered in light of these interdependences (Roberts, 2007). This need for harmonization between elements of strategy and dimensions of organizational structure (e.g. formalization, centralization and specialization) means that strategy and organization should be developed simultaneously, in a holistic manner (Roberts, 2007).

However, achieving this fit between strategy and structure is an extremely demanding and time consuming process, which includes consideration and interaction of a large number of elements. In that sense, some of the authors (e.g. Venkatraman, 1989; Stanford, 2007) emphasize that none of the organizations are in the state of perfect fit, but they are moving in that direction. As previous studies have shown, success is the issue of dynamic adjustment, rather than a static fit (Zajac et al., 2000). Therefore, organization should reflect fit but also the organizational flexibility and adaptability to the changing environment. While fit is often considered unique and identical for all organizations that work in a similar environment the necessity of its alignment with the changing environment is not emphasized. This approach, however, proved to be inadequate in explaining complex phenomena such as effective strategy formulation and implementation. Therefore, the modern approach 
Management, Vol. 22, 2017, 1, pp. 85-102

A. Aleksić, S. Rašić Jelavić: Testing for strategy-structure fit and its importance for ...

focuses on multivariate fit between several variables, including the environment and different organizational variables (Park et al., 2011) and their compliance with the strategy of the firm. Due to differences in organizational variables, fit is considered unique for each firm. However, the fit need to be adaptable in order to adjust to environmental changes or changes in certain elements of the organization.

Park et al. (2011) used terms micro-fit and macro-fit instead of external and internal fit to mark the difference between the internal and external compliance. Macro-fit is defined as the creation and maintenance of links between an organization (strategy and structure) and the environment or as an inter-organizational relationship aimed at achieving and sustaining a high level of organizational performance. In contrast, micro-fit is defined as the creation and development of a strong relationship between strategy and structure, or intra-organizational relations. In order to achieve higher levels of organizational performance, fit should exist both at the macro and micro levels of the organization.

Further studies have led to the identification of many different perspectives, structure and frameworks for evaluation of the fit. For example, Miles and Snow (1984) identified one of the earliest structural perspectives to evaluate the fit through the typology of strategic types; Burton and Obel (2004) formed their model of the fit in relation to requirements for an effective organizational design; Newport et al. (1991) differ among hierarchical levels of fit in the organization. Similarly, Kathuria et al. (2007) examine the difference between vertical and horizontal alignment. Each of the presented dimensions and perspectives of fit provides certain value through its conception and presentation. Common to all of them is the necessity to create fit among organizational elements that support defined strategy and between the organization and its environment to achieve the long-term survival of the firm and a desired performance.

\section{MILES AND SNOW TYPOLOGY}

As previously mentioned, Miles and Snow (1984) identified one of the earliest structural perspectives to evaluate fit through the typology of strategic types. This is one of the most enduring and valuable systems of strategy classification (Desarbo et al., 2005; Sollosy et al., 2015). It considers organization as an integral and dynamic entity - taking into consideration relationship between strategy, structure and processes. Strategy presents a way of alignment between the organization and its environment. Internal structures 
Management, Vol. 22, 2017, 1, pp. 85-102

A. Aleksić, S. Rašić Jelavić: Testing for strategy-structure fit and its importance for ...

and processes, in turn, have to be in line with the defined strategy to enable successful adjustment to the environment. In this process, organizations face not only the "entrepreneurial" problem (which strategy to adopt), but also the "administrative" problem (choice of structures and processes will be in line with defined strategy) (Andrews et al., 2009).

Strategies and organization types differ, according to Miles and Snow, primarily in questions regarding capital investment, concern for quality, price levels relative to competitors, preference in product innovation and preferences in the innovation process (Burton et al., 2006). Consequently, it is possible to distinguish between four types of strategies: (1) defenders (2) prospectors, (3) analysts and (4) reactors.

Defenders stand for types of organizations that try to find and sustain safe market niche on a relatively stable market. With limited number of products they focus on a narrow market segment. Within their domain, defenders act strongly to prevent competition from entering into their territory by offering higher quality, superior service and lower prices. Hence, such organizations engage in little or no new product/market development. In order to achieve this, they put emphasis on production efficiency (Snow and Hrebiniak, 1980) so they aim to achieve strict control of the organization in order to ensure efficiency. This is being addressed through a combination of structural and procedural mechanisms which can be described as mechanical and this type of organization often resembles classical bureaucracy (Meier et al., 2010). The structure itself can be designed for optimal efficiency through the extensive division of labor and relatively simple coordination mechanism, including a high degree of formalization and centralized control and decision-making, with communication through formal hierarchical channels (Miles et al., 1978; Ingram et al., 2016)

Prospectors seek an environment that is more dynamic and operate in a wide field of production, experiencing frequent changes. Primary capability is to find and exploit new product and market opportunities. Due to frequent changes, this type of strategy requires high degree of flexibility, and organizations need to be able to utilize and coordinate resources among a number of decentralized units and projects instead of centralizing planning and controlling of operations at organizational level. The primary aim is to achieve flexibility so organizational structure is more organic and characterized by a low level of complexity and formalization, high level of coordination and decentralized decision-making (Robbins and Barnwell, 2006). 
Analysers present a unique combination of defenders and protectors, as a kind of alternative to the two aforementioned strategies. The goal is to maintain a stable, limited line of products or services, while simultaneously responding quickly to selected market opportunities. After careful observation of key competitors' activities in the existing products area, this type of organization is often the second in the market with similar/same product and/or service but with lower prices (Snow and Hrebiniak, 1980).

In order to meet the need for stable and dynamic activities, organizational structure is characterized by moderately centralized control system with vertical and horizontal relationships. Such structure helps to ensure the balance between efficiency-based activities and the flexible ones (Shoham and Lev, 2015). Coordination mechanisms are extremely complex and costly (Miles et al., 1978). They combine a narrow structure of current and stable activities with the development of flexible structures for new activities with expected uncertainty.

Reactors present organizations that do not have a defined strategy or mode of operation. They are prone to instability and react inappropriately to environmental uncertainty. The organization is usually not persistent in maintaining established markets and products, unlike their competitors. Neither of them is willing to take risks as other competitors. Instead, the organization responds to those areas where there are strong pressures from the environment (Snow and Hrebiniak, 1980). This type of strategy can be considered as a form of "strategic collapse" due to inconsistencies between the strategy, technology, structures and processes (Miles et al., 1978). There is no clearly defined strategy of the organization; organizational structure is usually not designed in accordance with the selected strategy and it is often out of balance with the changes in the environment (Miles et al., 1978). The existing literature suggests that reactors, unlike defenders and prospectors, do not have predictable organizational structure but they lean towards centralization and formalization (Meier et al., 2010). Basic characteristics of different strategic types can be summarized in Table 1.

It is important to emphasize, however, that although organizations can operate on different markets and with different types of products, which implies that there may be several different types of strategies, generally organizations belong to one of four types of strategy. 
Management, Vol. 22, 2017, 1, pp. 85-102

A. Aleksić, S. Rašić Jelavić: Testing for strategy-structure fit and its importance for ...

Table 1. Basic characteristics of organizations according to Miles and Snow typology

\begin{tabular}{|l|l|l|l|}
\hline Strategy & \multicolumn{1}{|c|}{ Goals } & Environment & \multicolumn{1}{|c|}{ Structural characteristics } \\
\hline Defender & $\begin{array}{l}\text { stability } \\
\text { and } \\
\text { efficiency }\end{array}$ & stable & $\begin{array}{l}\text { higher specialization and detailed division } \\
\text { of labour; high degree of formalization; } \\
\text { centralization; strong control }\end{array}$ \\
\hline Analyst & $\begin{array}{l}\text { stability } \\
\text { and } \\
\text { flexibility }\end{array}$ & changeable & $\begin{array}{l}\text { less specialization; lower level of division } \\
\text { of labour and formalization; } \\
\text { decentralization }\end{array}$ \\
\hline Reactor & not defined & $\begin{array}{l}\text { in general } \\
\text { control over current activities; reduced } \\
\text { stable and } \\
\text { monopolistic } \\
\text { of formalization and centralization }\end{array}$ \\
\hline
\end{tabular}

Source: Robbins, S. P., Barnwell, N. (2006) Organization Theory, Concepts and Cases. Frenchs Forrest Australia: Pearson Prentice Hall, pp. 160.

\section{METHODOLOGY OF THE EMPIRICAL RESEARCH}

\subsection{Sample}

In our research, we want to test the relationship between strategy-structure fit and its importance for organizational performance. In line with the theoretical framework presented and previous results, we want to test if higher levels of strategy-structure fit lead to higher levels of organizational performance. In accordance with this, we propose the following hypothesis:

\section{H1. Higher levels of strategy-structure fit lead to higher levels of organizational performance.}

To test the proposed hypothesis, research methodology and instruments have been developed. The research was conducted using self-reported anonymous questionnaire that covered several fields related to organizational strategy, structure and performance. The questionnaire was sent to CEOs of medium and large sized organizations in Croatia. Out of 1731 medium and large sized organizations (data received from Croatian Chamber of Economy), 121 organizations responded to the questionnaire which represents a return rate of $7 \%$. However, out of 121 questionnaires, 8 of them did not satisfy research criteria, so they were excluded from further analysis. At the end 113 questionnaires were analyzed. Large sized organizations presented $57.52 \%$ of the sample and $81.42 \%$ of sampled organizations were in private or mostly 
Management, Vol. 22, 2017, 1, pp. 85-102

A. Aleksić, S. Rašić Jelavić: Testing for strategy-structure fit and its importance for ...

private ownership. Most of the sampled organizations were from manufacturing industry and retail, representing $16.8 \%$ of the sample.

\subsection{Measures}

Questionnaire consisted of different statements and questions whereby respondents were asked to provide their perception on their organization, strategy type, strategy implementation, and formalization, centralization and specialization as basic dimensions of organizational structure. Questionnaire items were adopted from prior studies, and measured on a five point Likert-type scale (response options ranged from $1=$ "never" to $5=$ "always").

In assessing organizational strategy, we used two sets of questions. First, we asked respondents to define the type of strategy their organizations apply on the organizational level. We asked respondents to read description of each type of strategy (i.e. defender, prospector, analyst and reactor) and define which type of strategy corresponds to their organization in the period the research was conducted. The self-placement of organizations into one of the four types of strategic orientation is a commonly used method in empirical research (Gnjidic, 2014). Description of strategies was adjusted from the questionnaire proposed by Snow and Hrebiniak (1980). The second set of questions assessed success of organizations in strategy implementation which implies the existence of critical factors that lead to successful implementation. For this purpose, we used items developed by Andrews et al. (2009) (7 items, $\alpha=0.914)$.

Items measuring organizational structure elements, i.e. level of formalization ( 3 items, $\alpha=0.737$ ), centralization ( 7 items, $\alpha=0.851$ ) and specialization ( 3 items, $\alpha=0.567$ ) in organizations were adopted from Olson et al. (2005). Respondents were asked to assess how specified are the rules that define how activities are done in organization (i.e. level of formalization) and how much freedom is given to lower management levels for coordination and control in the organization (i.e. level of centralization).

As a measure of organizational success we have analyzed market share and profitability of the organization for the previous two years (4 items, $\alpha=0.834$ ). The aim was to find out if, and to what extent, their market share and profitability have increased, stagnated or decreased in comparison with previous two years (2011 compared with 2010 and 2009). 
Management, Vol. 22, 2017, 1, pp. 85-102

A. Aleksić, S. Rašić Jelavić: Testing for strategy-structure fit and its importance for ...

\section{DATA ANALYSIS AND RESULTS}

Data collected were analyzed in several stages and using various statistical methods in SPSS 18.0 software package. In order to test the reliability, i.e. the internal consistency of the variable used in the research instrument, Cronbach's alpha coefficients were used. Almost all calculated Cronbach's alpha coefficients, as previously indicated, were larger than the cut-off value of .70, which implies internal consistency of the scale's items (Feldt and Kim, 2008). The only exception was the coefficient related to the reliability of level of specialization $(\alpha=0.567)$. In spite of several interventions, the level of reliability could not be increased, so the variable level of specialization was excluded from further analysis.

Descriptive data analysis showed that organizations have moderate level of formalization (Mean=3.0295) and centralization (Mean=3.0771), and that they are, on average, successful in strategy implementation (Mean=.3805).

Table 2. Descriptive data analysis

\begin{tabular}{|l|c|c|c|}
\hline & N & M & SD \\
\hline Formalization & 113 & 3.0295 & .88703 \\
\hline Centralization & 113 & 3.0771 & .73739 \\
\hline Strategy implementation & 113 & 3.3805 & .80260 \\
\hline
\end{tabular}

Source: Research results.

As already mentioned, we asked respondents to define which statement best describes their overall organizational strategy. Data shows that majority of organizations consider themselves to be analysts (37.2\%) and prospectors (35.4\%), followed by defenders $(21.2 \%)$, while only a small number of them stated to be reactors $(6.2 \%)$ (see Table 3 ).

Assessing the level of strategy-structure fit was done through case-by-case analysis of responses whereby two criteria were used to define the level of fit. As one of the criteria of fit, we assessed if organization had structural characteristics that would be in accordance with the strategy they have defined since every type of strategy, as stated by Miles and Snow typology, has certain specific structural characteristics. As a second criteria, we analyzed how developed is the strategy implementation process, that is, how strategy implementation supports a defined strategy. In order to group organizations according to their level of fit, we used the cut off value of 3.0; if lower 
Management, Vol. 22, 2017, 1, pp. 85-102

A. Aleksić, S. Rašić Jelavić: Testing for strategy-structure fit and its importance for ...

indicating no presence of fit $<3.0$; if higher than 3.1 indicating presence of fit. Based on the criteria for fit, we grouped organizations into three groups: group 1 , with a misfit present, i.e. there is no fit between strategy and structural organizational characteristics nor between strategy and strategy implementation process; Group 2, with a partial fit present, i.e. there is a fit between strategy and structural organizational characteristics but not strategy and strategy implementation process or there is a fit between strategy and strategy implementation process but not between strategy and structural organizational characteristics, and Group 3, with a fit present, both with strategy and structural organizational characteristics, as well as with strategy and its implementation process.

Table 3. Descriptive analysis of strategy typology and fit

\begin{tabular}{|l|c|c|c|c|c|}
\hline $\begin{array}{c}\text { Strategy } \\
\text { type }\end{array}$ & N & $\begin{array}{c}\text { Percentage } \\
(\%)\end{array}$ & $\begin{array}{c}\text { GROUP 1 } \\
\text { No fit (\%) }\end{array}$ & $\begin{array}{c}\text { GROUP 2 } \\
\text { Partial fit (\%) }\end{array}$ & $\begin{array}{c}\text { GROUP 3 } \\
\text { Complete fit } \\
(\%)\end{array}$ \\
\hline Defenders & 24 & 21.2 & 20.8 & 37.5 & 41.7 \\
\hline Prospectors & 40 & 35.4 & 7.5 & 42.5 & 50.0 \\
\hline Analysts & 42 & 37.2 & 11.9 & 31.0 & 57.1 \\
\hline Reactors & 7 & 6.2 & 14.3 & 42.9 & 42.9 \\
\hline TOTAL & 113 & 100.0 & - & - & - \\
\hline
\end{tabular}

Source: Research results.

In order to test the importance of fit for organizational performance we used inferential statistics. We did one-way ANOVA to test for a statistically significant difference regarding performance between groups of different levels of fit.

Table 4. ANOVA results

\begin{tabular}{|l|c|c|c|c|c|}
\hline \multicolumn{7}{|c|}{ ANOVA } \\
\hline & Sum of Squares & df & Mean Square & F & Sig. \\
\hline Between Groups & 6,666 & 2 & 3,333 & 9,120 & .000 \\
\hline Within Groups & 40,201 & 110 &, 365 & & \\
\hline Total & 46,867 & 112 & & & \\
\hline
\end{tabular}

Source: Research results. 
Management, Vol. 22, 2017, 1, pp. 85-102

A. Aleksić, S. Rašić Jelavić: Testing for strategy-structure fit and its importance for ...

ANOVA shows no statistically significant difference $(\mathrm{p}<0.05)$ regarding performance between different groups of fit $(F(2,110)=9,120, p=0.000)$. In order to test where exactly do the differences exist, we performed Tukey HSD post hoc test. The test shows that there is a statistically significant difference regarding performance between groups that do not have fit (group 1) and those that have a complete fit (group 3) $(\mathrm{p}=0.00)$ and between groups that do not have fit (group 1) and those that have partial fit (group 2) $(p=0,00)$. Additionally, results show that there is no statistically significant difference between groups that have partial fit (group 2) and complete fit (group 3) ( $\mathrm{p}=$ $0,478)$.

Table 5. Tukey HSD post hoc test results

\begin{tabular}{|c|c|c|c|c|c|c|c|c|}
\hline \multirow{2}{*}{\multicolumn{2}{|c|}{ (I) fit }} & \multirow{2}{*}{\multicolumn{2}{|c|}{ (J) fit }} & \multirow{3}{*}{$\begin{array}{c}\begin{array}{c}\text { Mean } \\
\text { Difference } \\
\text { (I-J) }\end{array} \\
-.79167^{*}\end{array}$} & \multirow{3}{*}{$\begin{array}{c}\text { Std. } \\
\text { Error } \\
.18656\end{array}$} & \multirow{3}{*}{$\begin{array}{l}\text { Sig. } \\
.000\end{array}$} & \multicolumn{2}{|c|}{$\begin{array}{c}95 \% \text { Confidence } \\
\text { Interval } \\
\end{array}$} \\
\hline & & & & & & & Lower & Upper \\
\hline \multirow{6}{*}{ 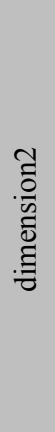 } & \multirow{2}{*}{$\stackrel{8}{-}$} & \multirow{2}{*}{ dimension3 } & $\begin{array}{l}2,0 \\
0\end{array}$ & & & & -1.2349 & -.3484 \\
\hline & & & $\begin{array}{l}3,0 \\
0 \\
\end{array}$ & $-.64881^{*}$ & .18032 & .001 & -1.0772 & -.2204 \\
\hline & \multirow{2}{*}{$\begin{array}{l}8 \\
i \\
i\end{array}$} & \multirow{2}{*}{ dimension3 } & $\begin{array}{l}1,0 \\
0 \\
\end{array}$ & $.79167^{*}$ & .18656 & .000 & .3484 & 1.2349 \\
\hline & & & $\begin{array}{l}3,0 \\
0 \\
\end{array}$ & .14286 & .12294 & .478 & -.1492 & .4349 \\
\hline & \multirow{2}{*}{$\begin{array}{l}8 \\
\text { mi }\end{array}$} & \multirow{2}{*}{ dimension3 } & $\begin{array}{l}1,0 \\
0 \\
\end{array}$ & $.64881^{*}$ & .18032 & .001 & .2204 & 1.0772 \\
\hline & & & $\begin{array}{l}2,0 \\
0\end{array}$ & -.14286 & .12294 & .478 & -.4349 & .1492 \\
\hline
\end{tabular}

Source: Research results.

Since there are clearly differences, additional correlation analysis was done. Pearson's correlation coefficient has revealed statistically significant positive relationship between increase in the level of fit i.e. higher levels of fit and organizational performance $(\mathrm{r}=.203 \mathrm{p}=0.031<.05, \mathrm{~N}=113)$.

However small, this correlation indicates positive association, testifying that higher level of strategy-structure fit leads to higher organizational performance. 
Management, Vol. 22, 2017, 1, pp. 85-102

A. Aleksić, S. Rašić Jelavić: Testing for strategy-structure fit and its importance for ...

Table 6. Correlation analysis results

\begin{tabular}{|l|l|c|c|}
\hline \multicolumn{2}{|l}{} & Fit & Performance \\
\hline \multirow{3}{*}{ Fit } & Pearson Correlation & 1 & $.203^{*}$ \\
\cline { 2 - 4 } & Sig. (2-tailed) & & .031 \\
\cline { 2 - 4 } & N & 113 & 113 \\
\hline
\end{tabular}

Source: Research results.

\section{DISCUSSION AND CONCLUSION}

Testing for strategy-structure fit and its importance for organizational performance was the subject of this study. Our goal was to give a theoretical overview of the characteristics of the strategy-structure fit and its influence on performance, as well as to give the overview of different approaches in the studies on fit. By using Miles and Snow typology, we aimed to give some additional insights into creating strategy-structure fit and to prove once more its contribution and importance for organizational performance. Cross-sectional field research investigated fit through strategy, structure and strategy implementation process fit, as well as performance among companies in Croatia. Results show that more than half of the organizations from the sample have realized the importance of fit so that, in the period the research was conducted, their organizational structure (with certain level of formalization and centralization) and the process of strategy implementation is in accordance with the defined strategic direction. Only a small number of organizations do not have fit among the analyzed variables. Statistical analyses among different groups i.e. levels of organizational fit, reveals that there is a statistically significant difference regarding performance between groups that do not have fit and those that have a partial or complete fit.

It is interesting that the results of the ANOVA test show no statistically significant difference between groups that have partial fit and complete fit. This implies that at least partial fit among strategy and structure or strategy and strategy implementation process is important for higher organizational performance. However, as further analysis and correlation analysis showed, higher levels of strategy-structure fit lead to higher organizational performance. Thus, organization should not focus only on some aspects of fit but should try to achieve strategy, structure and strategy implementation process fit or, in other words, they should try to design structure and the implementation process to support a defined organizational strategy. This leads us to confirm the research 
Management, Vol. 22, 2017, 1, pp. 85-102

A. Aleksić, S. Rašić Jelavić: Testing for strategy-structure fit and its importance for ...

hypothesis that higher levels of strategy-structure fit lead to higher levels of organizational performance.

These research findings should be examined in the light of certain limitations. The first limitation is related to the methodology used i.e. the questionnaire itself. Measures used were self-reports, leading to potential problem of subjectivity and the problem of common-method bias. As a measure of strategic type we used self-typing. As mentioned previously, this is a commonly used method in empirical research (Gnjidic, 2014). However, in this research, this perceptive nature of measures seems to create room for the majority of organizations in the sample to describe themselves primarily as analysts and prospectors which can be very questionable. As some authors emphasize (e.g. Conant et al., 1990), Miles and Snow strategic typology needs to be operationalized by using multiple measures and a more dynamic view of the organization should be taken into account. In view of that, future research should rely on more objective measures and facts.

Furthermore, this research measures organizational fit, relying on Miles and Snow typology and on the analysis of the relationship strategy-structureimplementation process. Other antecedents of fit could be analyzed, offering view on fit from multiple levels of analysis. The present research only measured strategy-structure fit as part of the internal fit. Gutterman (2015) emphasizes that organization should not be seen solely through organizational structure since it also includes a variety of additional elements such as the information and reward systems, management and decision making processes, organizational culture, strategy and human resources. Similarly, Roberts (2007) considers organization as a system of individuals, structural, cultural and organizational routines that refer to managerial processes, formal and informal politics and procedures. Therefore, future research might take into account some other measures of testing the presence and importance of fit. In other words, it should consider other elements of internal fit as well as the presence and analysis of external fit which has also been seen as a significant antecedent of performance. Finally, compared to the overall population, our sample is relatively small and more general conclusions would be drawn from larger, more heterogenic sample.

Despite potential limitations, we believe that this paper has offered an insight into the presence and importance of strategy-structure fit in organizations in Croatia. The study offers an in-depth theoretical and empirical view of strategy-structure fit and raises some additional questions which could be further analyzed in future research on this subject. 
Management, Vol. 22, 2017, 1, pp. 85-102

A. Aleksić, S. Rašić Jelavić: Testing for strategy-structure fit and its importance for ...

\section{REFERENCES}

1. Aagaard, A. (2016). Sustainable Business. Integrating CSR in Business and Functions. Gistrup: River Publishers.

2. Aleksic, A. (2012). Uloga organizacijskog dizajna u razvoju organizacijskih sposobnosti poduzeća, Doctoral thesis. Zagreb: Ekonomski fakultet Zagreb.

3. Andrews, R. W., Boyne, G. A., Law, J., Walker, R. M. (2009) Strategy, Structure and Process in the Public Sector: A Test of the Miles and Snow Model, Public Administration, 87 (4), pp. $732-749$.

4. Burke, W. W., Litwin, G. H. (1992). A Causal Model of Organizational Performance and Change, Journal of Management, 18 (3), pp. 523-545.

5. Burton, R. M., Obel, B. (2004). Strategic Organizational Diagnosis and Design: The Dynamics of Fit. New York: Springer.

6. Burton, R. M., DeSanctis, G., Obel, B. (2006). Organizational Design, A Step-by-Step Approach. New York: Cambridge University Press.

7. Camuffo, A., Wilhelm, M. (2016). Complementarities and Organizational (Mis)fit: A Retrospective Analysis of the Toyota Recall Crisis, Journal of Organization Design, 5 (4), doi:10.1186/s41469-016-0006-6

8. Carmeli, A., Tishler, A. (2004). The Relationships Between Intangible Organizational Elements and Organizational Performance, Strategic Management Journal, 25 (13), pp. 1257-1278.

9. Conant, J. S., Mokwa, M. P., Varadarajan, P. R. (1990). Strategic Types, Distinctive Marketing Competencies and Organizational Performance: A Multiple Measures-Based Study, Strategic Management Journal, 11 (5), pp. 365-383.

10. Cunliffe, A. L. (2008). Organization Theory. London: Sage Publications

11. Desarbo, W. S., di Benedetto, C. A., Song, M., Sinha, I. (2005). Revisiting the Miles and Snow Strategic Framework: Uncovering Interrelationships Between Strategic Types, Capabilities, Environmental Uncertainty, and Firm Performance, Strategic Management Journal, 26 (1), pp. 47-74.

12. Feldt, L. S., Kim, S. (2008). A Comparison of Tests for Equality of Two or More Independent Alpha Coefficients, Journal of Educational Measurement, 45 (2), pp. 179-193.

13. Garengo, P., Bernardi, G. (2007). Organizational Capability in SMEs Performance Measurement as a Key System in Supporting Company Development, International Journal of Productivity and Performance Management, 56 (5/6), pp. 518-532.

14. Gnjidic, V. (2014). Researching the Dynamics of Miles and Snow's Strategic Typology, Management - Journal of Contemporary Management Issues, 19 (1), pp. 93-117. 
Management, Vol. 22, 2017, 1, pp. 85-102

A. Aleksić, S. Rašić Jelavić: Testing for strategy-structure fit and its importance for ...

15. Gutterman. A. S. (2015). Organizational Design. A Guide for Growth Oriented Entrepreneurs. http://alangutterman.typepad .com/files/od---elements-of-organizational-design.pdf (accessed 27 March 2017)

16. Hamilton, R. T., Shergill, G. S. (1992). The Relationship Between StrategyStructure Fit and Financial Performance in New Zealand: Evidence of Generality and Validity With Enhanced Controls, Journal of Management Studies, 29 (1), pp. 95-113.

17. Hill, A., Cuthbertson, R. (2011). Fitness Map: A Classification of Internal Strategic Fit in Service Organisations, International Journal of Operations \& Production Management, 31 (9), pp. 991-1021.

18. Hsieh, Y. H., Chen, H. M. (2011). Strategic Fit among Business Competitive Strategy, Human Resource Strategy, and Reward System, Academy of Strategic Management Journal, 10 (2), pp. 11-32.

19. Ingram, T., Kraśnicka, T., Wronka-Pośpiech, M., Głód, G., Głód, W. (2016). Relationships Between Miles and Snow Strategic Types and Organizational Performance in Polish Production Companies, Journal of Management and Business Administration Central Europe, 24 (1), pp. $17-$ 45.

20. Kates, A., Galbraith, J. R. (2007). Designing Your Organization, Using the Star Model to Solve 5 Critical Design Challenges. San Francisco: JosseyBass.

21. Kathuria, R., Joshi, M. P., Porth, S. J. (2007). Organizational Alignment and Performance: Past, Present and Future, Management Decision, 45 (3), pp. 503-517.

22. Marr, B. (2008). Managing and Delivering Performance - How Government, Public Sector and Non-for-Profit Organizations can Measure and Manage What Really Matters. Oxford: Elsevier.

23. Meier, K. J., O’Toole, Jr., L. J., Boyne, G. A., Walker, R. M., Andrews, R. (2010). Alignment and Results: Testing the Interaction Effects of Strategy, Structure, and Environment from Miles and Snow, Administration \& Society, 42 (2), pp. 160-192.

24. Miles, R. E., Snow, C. C. (1984). Fit, Failure and the Whole of Fame, California Management Review, 26 (3), pp. 10-28.

25. Miles, R. E, Snow, C. C, Meyer, A. D., Coleman, H. J, Jr. (1978) Organizational Strategy, Structure, and Process, The Academy of Management Review, 3 (3), pp. 546-562.

26. Miller, D. (1996) Configurations Revisited, Strategic Management Journal, 17 (7), pp. 505-512.

27. Nadler, D. A., Tushman, M. L. (1980). A Model for Diagnosing Organizational Behavior, Organizational Dynamics, 9 (2), pp. 35-51. 
Management, Vol. 22, 2017, 1, pp. 85-102

A. Aleksić, S. Rašić Jelavić: Testing for strategy-structure fit and its importance for ...

28. Newport, S., Dess, G. G., Rasheed, A. M. A. (1991). Nurturing Strategic Coherency, Strategy and Leadership, 19 (6), pp. 18-27.

29. Olson, E. M., Slater, S. F., Tomas, G., Hult, M. (2005). The Performance Implications of Fit Among Business Strategy, Marketing Organization Structure, and Strategic Behavior, Journal of Marketing, 69 (3), pp. 49-65.

30. Park, D., Chinta, R., Lee, M., Turner, J., Kilbourne, L (2011). Macro-fit Versus Micro-fit of the Organization With its Environment: Implications for Strategic Leadership, International Journal of Management, 28 (2), pp. 488-493.

31. Porter, M. (1996). What is Strategy, Harvard Business Review, 74 (6), pp. 61-78.

32. Robbins, S. P., Barnwell, N. (2006). Organisation Theory, Concepts and Cases. Frenchs Forrest Australia: Pearson Prentice Hall.

33. Roberts, J. (2007). The Modern Firm, Organizational Design for Performance and Growth. New York: Oxford University Press.

34. Shoham A., Lev S. (2015). The Miles and Snow Strategic Typology and its Performance Implications. In: Manrai A., Meadow H. (Eds.) Global Perspectives in Marketing for the 21st Century. Developments in Marketing Science: Proceedings of the Academy of Marketing Science, Cham: Springer, pp. 214-220.

35. Siggelkow, N. (2001). Change in the Presence of Fit: The Rise, the Fall, and the Renaissance of Liz Claiborne, Academy of Management Journal, 44 (4), pp. 838-857.

36. Snow, C. C., Hrebiniak, L. G. (1980). Strategy, Distinctive Competence, and Organizational Performance, Administrative Science Quarterly, 25 (2), pp. 317-336.

37. Sollosy, M., Guidice, R. M, Parboteeah, K.P. (2015). A Contemporary Examination of The Miles \& Snow Strategic Typology Through The Lens of Ambidexterity, Academy of Management Annual Meeting Proceedings, $1,11213$.

38. Stanford, N. (2007). Guide to Organisation Design. Creating Highperforming and Adaptable Enterprises. London: Profile Books Ltd.

39. Swoboda, B. (2016). The Impact of Fit among Internationalization Stages and Firms' Structure, Processes and Culture on Performance. In: Eckert, S., Trautnitz, G. (Eds.) Internationales Management und die Grundlagen des globalisierten Kapitalismus. Wiesbaden: Springer Fachmedien, pp. 59-82.

40. Venkatraman, N., Camillus, J. C. (1984), Exploring the Concept of Fit in Strategic Management, Academy of Management Review, 9 (3), pp. 513525. 
Management, Vol. 22, 2017, 1, pp. 85-102

A. Aleksić, S. Rašić Jelavić: Testing for strategy-structure fit and its importance for ...

41. Venkatraman, N. (1989). The Concept of Fit in Strategy Research: Toward Verbal and Statistical Correspondence, Academy of Management Review, 14 (3), pp. 423-444.

42. Xu, S., Cavusgil, S. T., White, C. (2006). The Impact of Strategic Fit Among Strategy, Structure, and Processes on Multinational Corporation Performance: A Multimethod Assessment, Joumal of International Marketing, 14 (2), pp. 1-31.

43. Zajac, E. J., Kraatz, M. S., Bresser, R. K. F. (2000). Modeling the Dynamics of Strategic Fit: A Normative Approach to Strategic Change, Strategic Management Journal, 21 (4), pp. 429-453.

\title{
UKLAPANJE IZMEĐU STRATEGIJE I STRUKTURE I TESTIRANJE NJEGOVOG ZNAČAJA ZA POSLOVNI UČINAK
}

\begin{abstract}
Sažetak
Razumijevanje različitih organizacijskih elemenata, njihov međusobni utjecaj, kao i njihovo međusobno usklađivanje su prepoznati kao značajan čimbenik poslovnog učinka. Ovi složeni odnosi, kao i potreba za kreiranjem usklađenosti, postavlja pitanje kako harmonizirati različite elemente organizacije, koji doprinose ukupnom učinku. U tom se smislu, o ovom radu raspravlja o pitanjima međusobne usklađenosti te se posebno analizira prisutnost i djelovanje usklađivanja strategije sa strukturom na poslovni učinak. Korištenjem tipologije Milesa i Snowa, utvrđuju se obrasci odnosa između strategije i njene implementacije, strukture te njihovog utjecaja na poslovni učinak. Dobiveni rezultati potvrđuju zaključke postojeće literature i naglašavaju zaključak o usklađenosti između strukture, strategije i procesa strateške implementacije, kao načina za postizanje viših razina učinka.
\end{abstract}

Ključne riječi: organizacija, strategija, struktura, usklađenost, poslovni učinak, Hrvatska 